\title{
鉄筋コンクリート造建築物の地震応答と等価線形化法に関する研究 STUDY ON EARTHQUAKE RESPONSE AND EQUIVALENT LINEARIZATION METHOD OF REINFORCED CONCRETE BUILDINGS
}

\author{
稲井栄一*，北村＼cjkstart梢**，丸橋奈々子***, 平石久廣**** \\ Eiichi INAI, Kozue KITAMURA, Nanako MARUBASHI \\ and Hisahiro HIRAISHI
}

\begin{abstract}
To improve the prediction of nonlinear response of RC buildings to the design input ground motions by the equivalent linearization method, a simple equation for the asymmetry of response is proposed based on the assumption of equal energy response in the positive and negative direction. Then, an equivalent linearization method considering the asymmetric steady state response by the proposed equation is introduced in this paper. The method shows excellent agreement with the results of the time history response analysis of a single-degree-of-freedom system with Takeda's hysteretic characteristics.
\end{abstract}

Keywords : Reinforced concrete buildings, Earthquake response, Time history response analysis,

Equivalent linearization method, Asymmetric steady state response Equivalent damping factor 鉄筋コンクリート造建築物, 地震応答, 時刻歴応答解析, 等価線形化法, 非対称定常応答, 等価減衰定数

1. はじめに

2000 年に導入された限界耐力計算では、地震時の応答值の算定に 等価線形化法が用いられており、建築物の減衰性能を表す等価減衰 定数として、告示 ${ }^{1)}$ には、剛性低下型バイリニアモデルの復元力特 性に基づいた算定式が示されている。また、この算定式の適用に際 しては、鉄筋コンクリート造建築物の復元力特性を等価バイリニア 型に置換する方法が示されている。しかしながら、剛性低下型バイ リニアモデルは、基本的には鉄筋コンクリート造特有のひび割れに よる履歴を考慮せずに簡略化したものであり、上記の告示の評価方 法の妥当性については十分な検証がなされているとは言い難い。ま た、地震応答の非定常性に関し、上記の等価減衰定数の算定式は、 対称定常応答状態における等価減衰定数を低減して定式化 ${ }^{2)}$ されて いるものの、等価線形化法に関する既往の研究 ${ }^{3), 4), 5)}$ において指摘 されている応答の偏りに起因する等価周期の変化（縮小）について の考慮はなされていない。

本論は、等価線形化法による設計用地震動に対する建築物の弾塑 性応答の推定精度の向上を目的とし、まず、曲げ降伏が先行する鉄 筋コンクリート造建築物の復元力特性として代表的なトリリニア 型の $\mathrm{Takeda}^{6}{ }^{6}$ モデルを用い、また、入力地震動として、設計用地震
動として用いられることの多いランダム位相の模擬地震動 25 波を 用いた 1 自由度系の時刻歴応答解析を行い、告示による応答の評価 法の検討を行った。その結果、告示の評価法は、ひび割れ領域の履 歴減衰が大きい場合には、Takeda モデルによる応答結果と整合しな いことを指摘している。また、解析結果を用いて等価周期の変化の 原因となる応答の偏りの分析を行い、応答の偏りと最大応答变位の 間に明瞭な関係があることを示すとともに、地震応答 1 サイクルに おける正側と負側の吸収エネルギーの対称性を仮定し、応答の偏り を評価する算定式を導いている。本算定式は模擬地震動 25 波の時 刻歴応答解析における偏りの平均值と良好に対応寸る。

さらに、本論では、上記の偏りに基づいた非対称の定常応答状態 を想定し、偏りが生じた場合の Takeda モデルの等価減衰定数およ び等価周期（等価剛性）の検討を行い、偏りを考慮した応答值の算 定法を示している。また、加速度一定領域および速度一定領域から なる設計用応答スペクトルに対する建築物のベースシア係数一最 大塑性率関係を定式化している。本算定法による最大塑性率は、模 擬地震動 25 波の時刻歴応答解析における最大塑性率の平均值と良 好に対応する。

なお、文献 ${ }^{33,4)}$ においては、既往の観測波を対象に、地震応答の
本論の内容の一部は既に文献13)に発表している。

* 山口大学大学院理工学研究科 教授 · 博士 (工学)

** 山口大学大学院理工学研究科 博士後期課程 · 大学院生

$* * *$ 山口大学大学院理工学研究科 助教・博士 (工学)

**** 明治大学理工学部建築学科 教授. 工博 (独立行政法人建築研究所 客員研究員)
Prof., Graduate School of Science and Eng., Yamaguchi Univ., Dr. Eng. Graduate Student, Graduate School of Science and Eng. Yamaguchi Univ.

Assistant Prof., Graduate School of Science and Eng., Yamaguchi Univ., Dr. Eng. Prof., Dept. of Architecture, School of Science and Technology, Meiji Univ., Dr. Eng.

(Visiting Research Fellow, Building Research Institute) 
瞬間エネルギー入力に着目し、最大応答が生じる 1 サイクルでの応 答の非対称性（偏り）の評価が行われている。本論では、定常性の 強いランダム位相の模擬地震動を用いていることから、偏りの評価 は正側負側の各々の最大応答変位により行っている。

\section{1 自由度系の時刻歴応答解析}

\section{1 解析モデル}

図 1 に解析に用いた 1 自由度系モデルを示す。図中、 $M_{e}$ は建築物 の有効質量である。 $H$ および $R$ は文献 ${ }^{7)}$ の定義による建築物の代表 高さおよび全体変形角で、建築物の代表高さでの応答変位 $\delta$ は $R \times$ $H$ で表される。解析に用いた水平ばねの復元力特性モデルは Takeda モデルで、トリリニア型のスケルトンカーブの特性を図 2 の記号を 用いて表した。正側と負側のスケルトンカーブは同一である。図 2 の縦軸 $Q$ は建築物のベースシア、横軸 $\delta$ は水平変形 (=応答変位) を表している。 $Q_{y}$ は降伏耐力、 $\delta_{y}$ は降伏変形、 $K_{y}$ は降伏点剛性であ る。また、 $\alpha_{y}$ は降伏点剛性低下率、 $\beta$ は降伏点剛性に対寸る降伏後 の剛性の比である。 $\lambda$ は $Q_{y}$ に対するひび割れ点の耐力の比、 $\eta$ は降 伏後の除荷剛性低下指数、 $\mu$ は塑性率 $\left(\mu=\delta / \delta_{y}\right)$ である。なお、Takeda

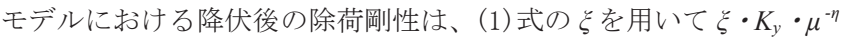
と表される。 の等価減衰定数 $h_{e, r}$ は、 $\xi$ を用いて (3a) 式のように簡便な形で表され る。また、ひび割れ点の変形を、(2)式の $\psi$ を用いて $\psi \cdot \delta_{y}$ と表せば、 ひび割れ後降伏までの $h_{e, r}$ は、 $\psi$ と $\xi を$ 用いて $(3 \mathrm{~b})$ 式で表される。

$$
\begin{aligned}
& \xi=\frac{1+\lambda}{1+\lambda \cdot \alpha_{y}} \quad \text { (1) } \quad \psi=\lambda \cdot \alpha_{y} \\
& h_{e, r}= \begin{cases}\frac{1}{\pi}\left[1-\frac{1}{\xi}\{1+\beta(\mu-1)\} \cdot \mu^{\eta-1}\right] & (\mu \geqq 1) \\
\frac{1}{\pi} \cdot \frac{1}{\mu} \cdot \frac{(1-1 / \xi)(\mu-\psi)}{\frac{2(\mu-1)}{\xi(\psi+1)}+2-\mu-\psi} & (\psi \leqq \mu<1)\end{cases}
\end{aligned}
$$

表 1 に、時刻歴応答解析に用いた解析モデルのパラメータを示す。 建築物の最上階までの高さ $H_{T}$ は $9 \mathrm{~m} 、 21 \mathrm{~m} 、 45 \mathrm{~m} の 3$ 種類、降伏耐 力 $Q_{y}$ は、ベースシア係数 $C_{B}\left[=Q /\left(M_{e} \cdot g\right) 、 g\right.$ は重力加速度 $]$ に換 算した降伏ベースシア係数 $C_{B, y}$ で 0.2 から 1.2 まで 0.1 刻みの 11

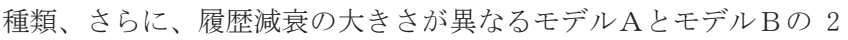
種類の復元力特性モデルを設定した。 $H_{T}$ が 3 種類、 $C_{B, y}$ が 11 種類で

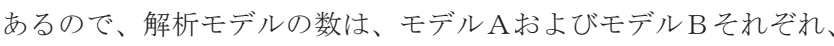
$3 \times 11$ で 33 個、合計 66 個である。

モデル Aおよびモデル B とも、降伏変形 $\delta_{y}$ は、降伏時全体変形角 $R_{y}$ と代表高さ $H$ の積で与え、 $H$ は文献 ${ }^{7)}$ と同様 7 階建て程度を想定 し $0.715 H_{T}$ とし、 $R_{y}$ は降伏耐力にかかわらず一定 ${ }^{8)}$ で $1 / 150$ とした。 また、 $\beta$ もともに 0.02 としている。ひび割れ点に関しては、モデル $\mathrm{A}$ もモデル B もひび割れ点の変形を $0.1 \delta_{y}\left[(2)\right.$ 式の $\left.\psi=\lambda \cdot \alpha_{y}=0.1\right]$ とし、履歴減衰の大きさが異なるように、モデルAでは $\alpha_{y}=0.5 、 \lambda$ $=0.2$ 、モデル B では $\alpha_{y}=0.2 、 \lambda=0.5$ としている。 $\alpha_{y}=0.5$ の值は、 標準的な值である $1 / 3$ より大きく、0.2 の值はこれよりも小さい。 また、 $\lambda=0.5$ の值は標準的な值である $1 / 3$ よりも大きく、0.2 の值 はこれよりも小さい。ひび割れ前の初期周期は、モデル A が $0.268 \mathrm{~s}$ 〜 $1.470 \mathrm{~s}$ 、モデル Bが $0.170 \mathrm{~s} \sim 0.930 \mathrm{~s}$ であり、後述の入力地震動 の加速度一定領域 $(0.16 \mathrm{~s} \sim 0.864 \mathrm{~s})$ または速度一定領域 $(0.864 \mathrm{~s}$ 以

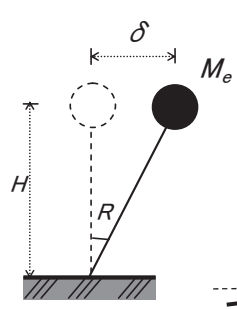

図1 1 自由度系モデル

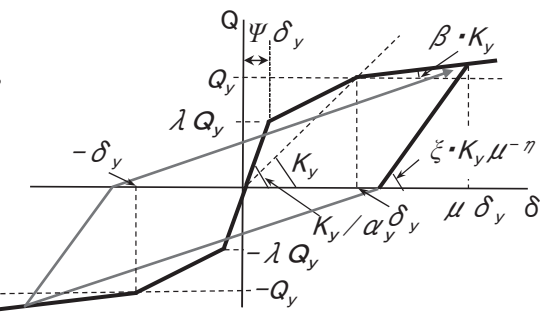

図2 復元力特性モデル

\begin{tabular}{|c|c|c|c|c|}
\hline$H_{T}$ & $9 m$ & $21 \mathrm{~m}$ & $45 m$ & \\
\hline \multirow{3}{*}{$C_{B, y}=Q_{y} /(M e \cdot g)$} & 0.2 & 0.3 & 0.4 & 0.5 \\
\hline & 0.6 & 0.7 & 0.8 & 0.9 \\
\hline & 1.0 & 1.1 & 1.2 & \\
\hline \multirow[b]{2}{*}{$\alpha_{y}$} & \multicolumn{2}{|c|}{ モデルA } & \multicolumn{2}{|c|}{ モデルB } \\
\hline & \multicolumn{2}{|c|}{0.5} & \multicolumn{2}{|c|}{0.2} \\
\hline$\lambda$ & \multicolumn{2}{|c|}{0.2} & \multicolumn{2}{|c|}{0.5} \\
\hline 共通事項 & \multicolumn{2}{|c|}{$\begin{array}{c}\delta_{y}=R_{y} \cdot H \\
\beta=0.02 \\
n=04\end{array}$} & \multicolumn{2}{|c|}{$\left(H=0.715 H_{T}, R_{y}=1 / 150\right)$} \\
\hline
\end{tabular}

表 1 解析モデルのパラメータ

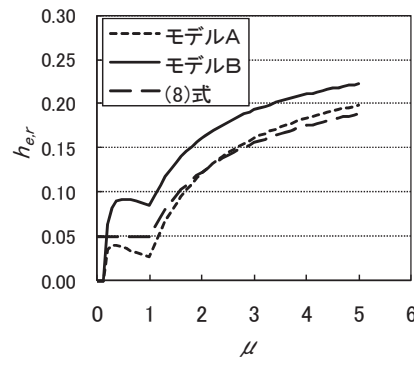

図3解析モデルの $h_{e, r}$

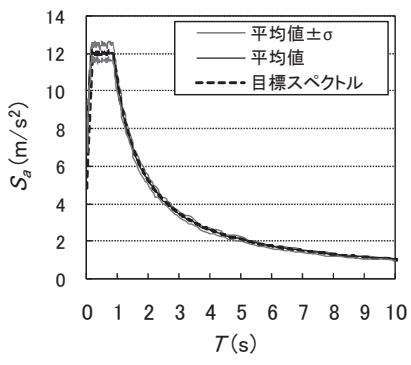

図4 加速度応答スペクトル

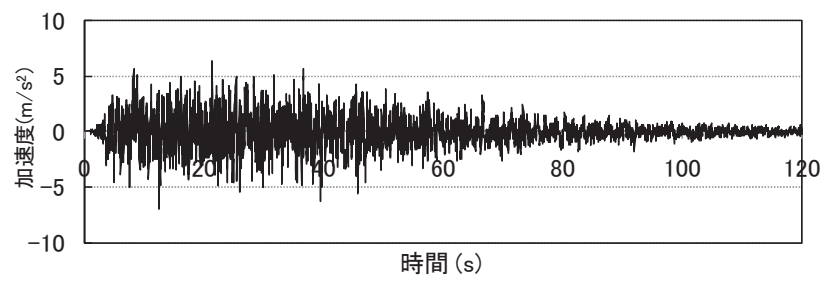

図5 入力地震動の一例

上)に存在する。

降伏後の除荷剛性低下指数 $\eta$ はモデル A もモデル B も 0.4 の值を 設定した。この 0.4 の值は、曲げ降伏する鉄筋コンクリート造の部 材、層、あるいは建築物の履歴性状を表す場合に適用される值であ る。(1)式の $\xi$ の值は、モデル A が 1.091、モデルBが 1. 364 であり、

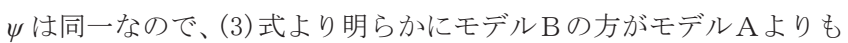
減衰が大きくなる。図 3 に両モデルの等価減衰定数 $h_{e, r}$ を示す。モ デル Aの降伏後の減衰定数は、告示の等価減衰定数 $h_{e}$ [後出の (8) 式 $]$ と同程度であるが、モデル B の減衰定数はそれよりも大きい。

\section{2 入力地震動}

時刻歴応答解析における入力地震動は、25 波の模擬地震動である。 これらは、(4)式で表される限界耐力計算で規定される地震地域係 数 $Z=1$ 、第 2 種地盤の加速度応答スペクトル $S_{a}$ (減衰定数 $h=0.05$ ) 1) に適合するように作成したもので、全て、ランダム位相、継続時 間は 120 秒で、包絡関数は文献 ${ }^{9)}$ のレベル 2 のものを用いた。(4) 式中 $T$ は周期 $(\mathrm{s})$ で、 $A=12 \mathrm{~m} / \mathrm{s}^{2} 、$ コーナー周期 $T_{\mathrm{c}}$ は $0.864 \mathrm{~s}$ である。 


$$
S_{a}= \begin{cases}A \cdot\left(0.4+\frac{0.6}{0.16} T\right) & (T<0.16) \\ A & \left(0.16 \leqq T<T_{c}\right) \\ \frac{A \cdot T_{c}}{T} & \left(T_{c} \leqq T\right)\end{cases}
$$

図 4 に、 $h=0.05$ における 25 波の $S_{a}$ の平均値と (平均值士標準偏 差 $\sigma$ ) の值を示す。 $0.16 \mathrm{~s} \leqq T \leqq 10 \mathrm{~s}$ における $S_{a}$ の平均値は $(4 \mathrm{~b})$ 式、 (4c) 式の $S_{a}$ に対して、0.98〜1.04 であり、両者はほぼ一致している。 また、 $0.16 \mathrm{~s} \leqq T \leqq 10 \mathrm{~s}$ における 25 波の変動係数は、2.4〜7.2\%であ る。図 5 に模擬地震動の一例を示す。

時刻歴応答解析は 66 個の解析モデルに対し、それぞれ 25 個の模 擬地震動を用いて行った。解析の総数は $66 \times 25$ で 1650 である。な お、時刻歴応答解析では、瞬間剛性比例型の粘性減衰を設定し、そ の減衰定数はひび割れ前の初期周期に対して $3 \%$ とした。また、時

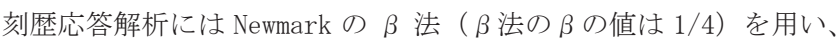
積分時間刻みは 0.002 秒とした。

\section{3 解析結果のベースシア係数一最大塑性率関係}

図 6 に、模擬地震動 25 波に対寸る各解析モデルの最大塑性率 25 個の平均值 $\mu_{a v}$ と応答ベースシア係数 $C_{B}$ （復元力特性モデル上で $\mu_{a v}$ に対応するベースシア係数）の関係を○印、 $\triangle$ 印、 $\square$ 印で示す。な お、図 6 では、実用的な範囲として $\mu_{a v} \leqq 5$ のものだけを示した（以 下の図においても同様とした)。図 7 には、各解析モデルの最大塑 性率の変動係数 $\left(\sigma_{\mu} / \mu_{a v}\right)$ と $\mu_{a v}$ の関係を示した。ここで、 $\sigma_{\mu}$ は模擬 地震動 25 波に対する各解析モデルの最大塑性率 25 個の標準偏差で ある。変動係数は $\mu_{a v}$ が大きいほど大きい傾向があり、最大 $20 \%$ 程 度となっている。

図 6 中の実線および破線は、(5)式の等価線形化法による $C_{B}-\mu$ 関係 $\left.{ }^{7)}, 8\right)$ の算定值で、(6) 式〜 (8) 式を用いて算定したものである。 実線は、これらの式の適用において、降伏点をトリリニア型のスケ ルトンカーブの降伏点とした場合である。一方、破線は、式の適用 における降伏点を、トリリニア型のスケルトンカーブと面積が等し

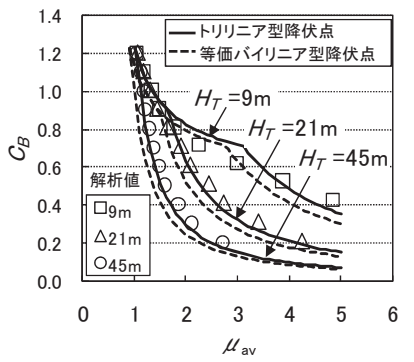

(a) モデル A

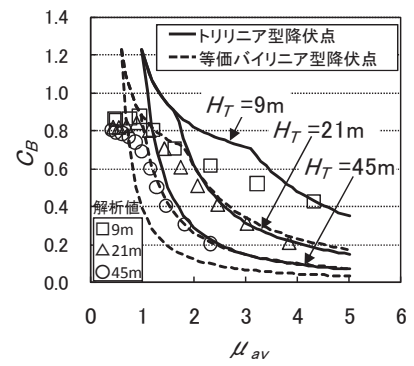

(b) モデル B

図 6 時刻歴応答解析結果と (5) 式の比較

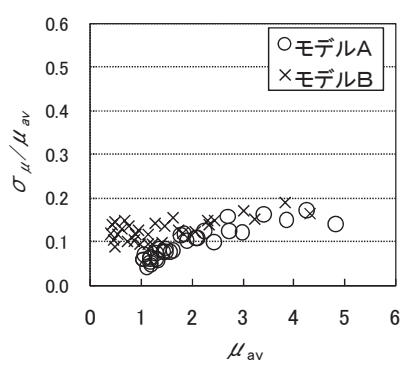

図 $7 \mu$ の変動係数

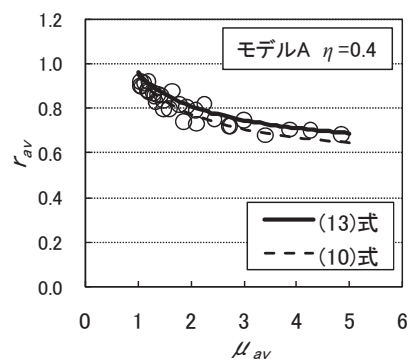

(a) モデル A

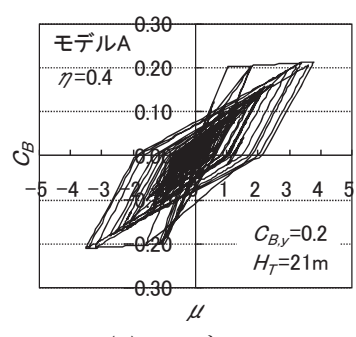

(a) モデル A
ただし、

$$
\begin{aligned}
& T_{e}= \begin{cases}\sqrt{\frac{\mu}{F_{h}}} \cdot 2 \pi \sqrt{\frac{R_{y} \cdot H}{A}} & \text { (加速度一定領域) } \\
\frac{\mu}{F_{h}} \cdot \frac{(2 \pi)^{2}}{A \cdot T_{c}} R_{y} \cdot H & \text { (速度一定領域) }\end{cases} \\
& F_{h}=\frac{1.5}{1+10 \cdot h_{e}} \quad(7) \quad h_{e}=0.25\left(1-\frac{1}{\sqrt{\mu}}\right)+0.05
\end{aligned}
$$

ここで、 $T_{e}$ は応答時の等価周期で (6) 式で表わされる。 $F_{h}$ は減 衰による応答加速度の低減率で、告示 ${ }^{1)}$ では (7) 式で与えられる。 また、（7) 式中の等価減衰定数 $h_{e}$ は主筋とコンクリートの付着 が適切に確保されている場合には(8)式で与えられる（ただし、 $\mu<1$ では $\left.h_{e}=0.05\right)$ 。(8) 式の第 1 項は、対称定常応答状態の剛 性低下バイリニアモデルの等価減衰定数に、過渡応答の平均的 な減衰の効果を考慮し、0.8 の低減係数を乗じて定められてい る。なお、(3a)式において、 $\xi=1 、 \beta=0 、 \eta=0.5$ と置き、 0.8 を乗じると、(3a)式は (8) 式の第 1 項と一致する。

図 $8 C_{B}-\mu$ 関係の一例

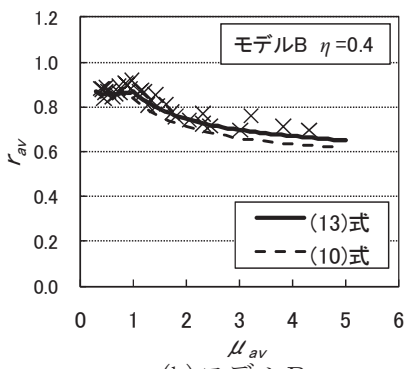

(b) モデル B

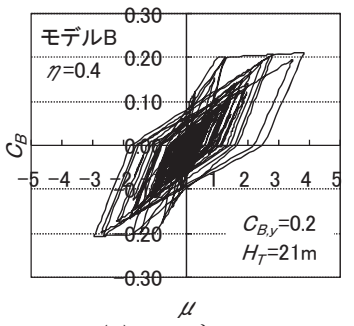

(b) モデル B
図 $9 \quad r_{a v}-\mu_{\mathrm{av}}$ 関倸

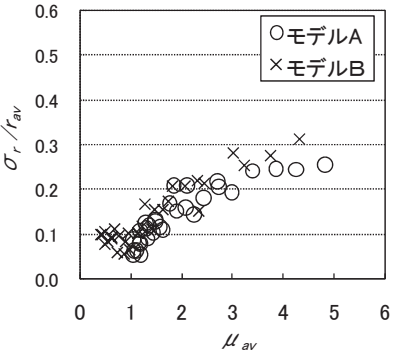

図 $10 \quad r$ の変動係数 


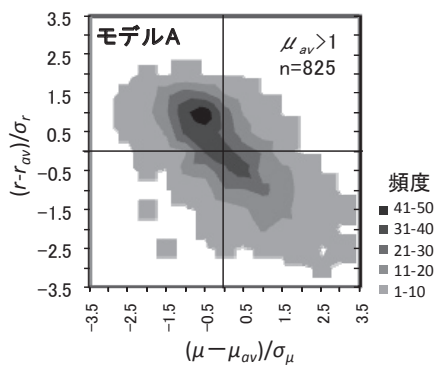

(a) モデル A

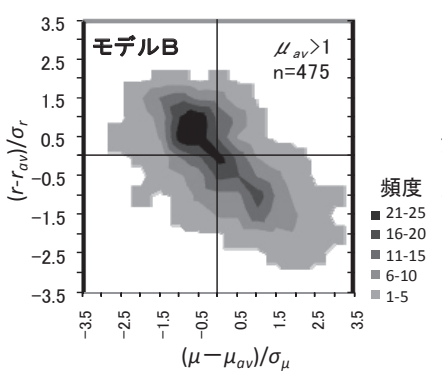

(b) モデル B $\left(\mu_{a v}>1\right)$

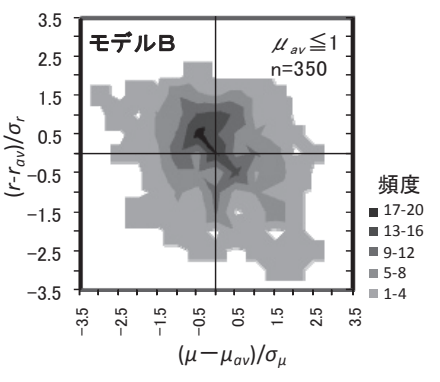

(c) モデル B $\left(\mu_{a v} \leqq 1\right)$

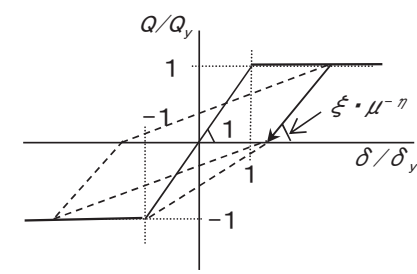

図 12 検討用復元力特性モデル

図 $11 \quad r$ と $\mu$ の頻度分布

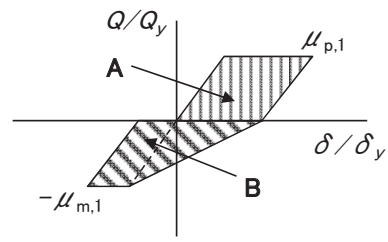

(a) 状態 1

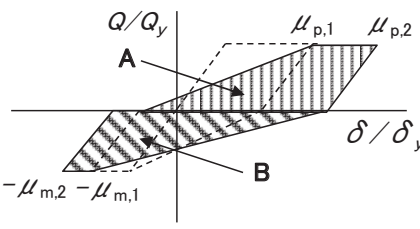

(b) 状態 2

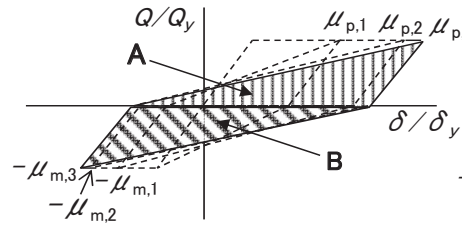

(c) 状態 3

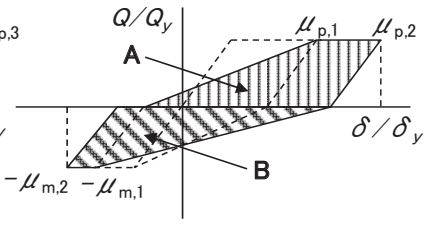

(d) 状態 2

図 13 正側負側の吸収エネルギーが等しい応答過程

\section{4 解析結果の応答の偏り}

図 8 に、時刻歴応答解析から得られた両モデルのベースシア係数 $C_{B}$ 一塑性率 $\mu$ 関係の一例を示す。これらは、同一の模擬地震動に対 する結果である。図 $8(b)$ に示すように、時刻歴応答解析では、復元 力特性が正負同一であっても、正側と負側における各々の最大応答 変位の絶対值は異なる場合が多く、応答に偏りが観られる。そこで、 正側負側にかかわらず最も絶対值が大きい応答変位を $\delta$ 、それと反 対側における最大応答変位を $-r \cdot \delta$ とし、すべての解析において $r$ を求めた。以下では、この $r$ を対称率と呼ぶ。 $r$ は、1の場合には応 答に偏りがないことを、1 より小さい場合には応答に偏りがあるこ とを表す。図 9 に、模擬地震動 25 波に対する各解析モデルの $r$ の值 25 個の平均值 $r_{a v}$ と前述の $\mu_{a v}$ の関係を○印、×印で示す。 $r_{a v}$ の值は $\mu_{a v}$ に対してばらつきが少なく、 $\mu_{a v}$ が 1 より小さい領域ではほぼ一 定で 0.9 程度であるが (図 9 (b) 参照)、 $\mu_{a v}$ が大きくなる程小さくな る傾向がある。なお、図中の実線および破線は後述の算定式の值で ある。また、図 10 に上記 $r$ の変動係数 $\left(\sigma_{r} / r_{a v}\right)$ を示す。ここで、 $\sigma_{r}$ は模擬地震動 25 波に対寸る各解析モデルの $r$ の值 25 個の標準偏差 である。 $r$ の変動係数は $\mu_{a v}$ が 1 より小さい範囲では $10 \%$ 程度である が、 $\mu_{a v}$ が大きくなるほど増大し、最大 $30 \%$ 程度になっている。

解析值の最大塑性率 $\mu$ および対称率 $r$ の平均值からのばらつきを 調べるため、各解析モデルにおいて、 $\left(\mu-\mu_{a v}\right) / \sigma_{\mu}$ および $\left(r-r_{a v}\right) / \sigma_{r}$ の值を算出した。図 11 (a)に、モデルAの場合におけるこれらの值 の頻度分布（総数 $n=825 ）$ を示す。また、図 11 (b) にモデルBで $\mu_{a v}$

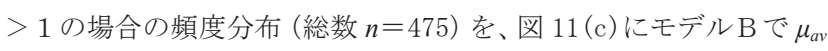
$\leqq 1$ の場合の頻度分布（総数 $n=350 ）$ を示す。なお、モデルAの 場合は全ての解析モデルで $\mu_{a v}>1$ である。頻度は、縦軸横軸とも 0.5 刻みで求め、 5 段階に分類して濃淡で表した。濃いものほど頻 度が高い。図 11 (c) に示寸ように、 $\mu_{a v} \leqq 1$ の場合は、円に近い形状 で解析值が分布しており両者の相関は弱い（相関係数 $=-0.27 ） 。$ 一方、図 11 (a) および図 11 (b) に示すように、 $\mu_{a v}>1$ の場合は、解 析值は 45 度傾いた楕円に近い形状で分布しており、 $r$ が $r_{a v}$ より小 さい場合、 $\mu$ が $\mu_{a v}$ より大きくなる傾向がある。また、 $r$ が $r_{a v}$ より
大きい場合、 $\mu$ が $\mu_{a v}$ より小さくなる傾向がある。相関係数は図 11 (a) がー0.68、図 11 (b) がー0.69 である。これらのことは、塑性 化した場合における最大応答変位の推定には、応答の偏りを考慮 する必要性を示唆している。

\section{3. 応答の偏りの評価 \\ 3.1 対称率の算定式}

ここでは、応答の偏りを評価するため、図 12 に示す Takeda モ デルを簡略化した復元力特性モデルを用いる。降伏後の除荷剛性 は、図 2 と同様に(1)式の $\xi$ を用いて表し、降伏後剛性は 0 とする。

解析に用いた模擬地震動の各周期での正側と負側の弾性最大応 答変位（ $5 \%$ 減衰）の比は、 25 波の平均值が $0.94 \sim 1.06(0.16 \mathrm{~s} \leqq$ $T \leqq 10 \mathrm{~s} ）$ であり、変動係数は $0.05 \sim 0.15$ である。個々の地震動に は変動があるものの、平均的には、弾性時にはほぼ正負対称の最 大応答変位が生じ、系のポテンシャルエネルギーは対称である。 以下では、塑性化が生じても系に入力されるエネルギーの対称性 は保たれるものと仮定する。また、模擬地震動の包絡関数は時間 的变化が比較的緩やかであることから、応答は最大応答まで徐々 に増大していくものとし、以下に示す応答過程を想定する。

まず、図 13 (a)に示すように、応答の 1 サイクル中の正側と負側 の $1 / 2$ サイクルの吸収エネルギー（図中の面積 $\mathrm{A}$ と面積 B ）が等 しい原点から始まる応答状態を想定する。ただし、最大応答変位 は正側で生じるものとする。この場合、正側の最大塑性率を $\mu_{p, I}$ 負側の最大塑性率を一 $\mu_{m, l}$ とすると (9) 式が成立する。

次に、図 13(b)のように、図 13 (a) の状態から応答が大きくなっ た状態を考える。ただし、同様に、1/2 サイクルの吸収エネルギー を表す面積 $\mathrm{A}$ と面積 B は等しいものとする。正側の最大塑性率を $\mu_{p, 2}$ 、負側の最大塑性率を一 $\mu_{m, 2}$ とすると同様に (9) 式が成立する。

図 13 (c)の状態は、さらに、1/2 サイクルの吸収エネルギーが等 しくなるように、正側の最大塑性率が $\mu_{p, 3 、}$ 、負側の最大塑性率が 一 $\mu_{m, 3}$ に進行し、そこで非対称の定常応答状態に至った場合を表し ている。この状態においても正負の $1 / 2$ サイクルの吸収エネルギ 
一 (図 13 (c)の面積A と面積B) は等しく、(9)式が成立する。な お、応答の 1 サイクルにおける正側負側の $1 / 2$ サイクルの吸収エ ネルギーの対称性の仮定に関しては、付録 1 に検討結果を示した。 また、(9)式の誘導の詳細は付録 2 に示した。

(9)式において、 $r=\mu_{m, i} / \mu_{p, i}$ とし、 $\mu_{p, i}$ を最大塑性率 $\mu$ に置き換え ると、(10)式が得られる。対称率 $r$ は (10) 式で表される方程式の解 として求めることができる。

$\mu_{m, i}-\frac{1}{2 \xi} \mu_{m, i}{ }^{\eta}=\frac{1}{2} \mu_{p, i}(i=1,2,3) \quad$ (9) $\quad r-\frac{1}{2 \xi} \mu^{\eta-1} \cdot r^{\eta}=\frac{1}{2}$

また、図 13 (d) に示寸ように、正側の除荷領域（応答のピークか ら荷重 0 に至る領域 $)$ の放出エネルギー $\left[1 /(2 \xi) \cdot \mu_{p, i}{ }^{n}\right]$ と負側の除 荷領域の放出エネルギー $\left[1 /(2 \xi) \cdot \mu_{m, i}{ }^{n}\right]$ を、応答の各段階において 近似的に等しいとみなせば、正側と負側の荷重 0 から応答のピー クまでの $1 / 4$ サイクルの吸収エネルギーは等しくなる。この場合、 $\left[1 /(2 \xi) \cdot \mu_{p, i}{ }^{\eta}\right]=\left[1 /(2 \xi) \cdot \mu_{m, i}{ }^{\eta}\right]$ の関係を(9) 式に代入すると (11) 式が得られる。 $r$ は同様に（12）式で表すことができる。また、図 12 の復元力特性モデルの対称定常応答状態における等価減衰定数 $h_{e, r}$ は(3) 式で $\beta=0$ としたものになることから、 $\beta=0$ とする(3)式 を用いて (12)式の $\left[1 / \xi \cdot \mu^{\eta-1}\right]$ を消去すれば、対称率 $r$ は (13)式で表 すことができる。(13) 式は、等価減衰定数 $h_{e, r}$ が大きいほど、対称 率 $r$ が小さくなることを示している。図 14 に降伏後の除荷剛性低 下指数 $\eta$ を 0 と 0.7 とした場合について、正側の応答が等しいと し、正負の $1 / 4$ サイクルの履歴面積が等しくなるように定めた負 側の応答を示す。履歴減衰が大きい場合（ $\eta=0$ の場合）には負側 の応答は小さく（対称率 $r$ は小さく）なり、履歴減衰が小さい場合 $(\eta=0.7$ の場合）には負側の応答は大きく（対称率 $r$ は大きく） なることが分かる。

$$
\begin{aligned}
\mu_{m, i} & =\frac{1}{2} \mu_{p, i}+\frac{1}{2 \xi} \mu_{p, i}{ }^{\eta}(i=1,2,3) \quad \text { (11) } \quad r=\frac{1}{2}\left(1+\frac{1}{\xi} \mu^{\eta-1}\right) \\
r & =1-\frac{\pi}{2} \cdot h_{e, r}
\end{aligned}
$$

\section{2 算定式と解析結果の比較}

前出の図 9 における実線は(13)式を表したものである。(13)式 中の $h_{e, r}$ の算定には(3)式を用いた (以下、同様)。(13)式は $\mu>1$ を対象とした図 13 の応答過程から得られたものであるが、モデル $\mathrm{B}$ の場合の $\mu \leqq 1$ の領域でも解析結果と良好に対応している。また、 図 9 中の破線は、（10)式を表したものであるが、(13)式より若干 小さな值を与える。なお、(12) 式は $\mu>1$ の範囲の (13) 式とほぼ一 致するので比較を省略した。また、（13）式は $\mu \leqq 1$ の領域でも解析 結果と良好に対応していることから、以下の検討においては $r$ の算 出式として (13)式を用いることにする。

前述のように、(13) 式の $r$ は履歴減衰の影響を受ける。そこで、 $H_{T}=21 \mathrm{~m}$ の場合のみを対象として、モデルAおよびモデル B におい て、 $\eta$ の值を 0 および 0.7 とする時刻歴応答解析を別途実施した。 解析モデルの降伏ベースシア係数 $C_{B, y}$ は、 2.1 節と同じで、 0.2 から 1.2 までの 11 種類とした。入力地震動も 2.2 節に記した模擬地震動 25 波である。図 15 に、解析より得られた $r_{a v}-\mu_{a v}$ 関係 ( ○印、 $\diamond$ 印、 $\triangle$ 印）と (13) 式を比較して示す。解析結果は、 $\eta$ が大きくなるほど、 すなわち、履歴減衰が小さくなるほど $r$ は 1 に近づいており、(13) 式はこの傾向を良好に表している。また、図 16 に解析より得られ

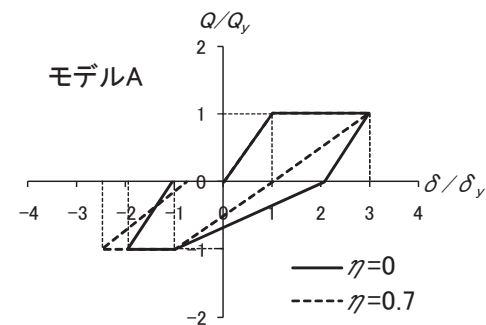

図 14 履歴減衰の違いによる対称率 $r$ の変化

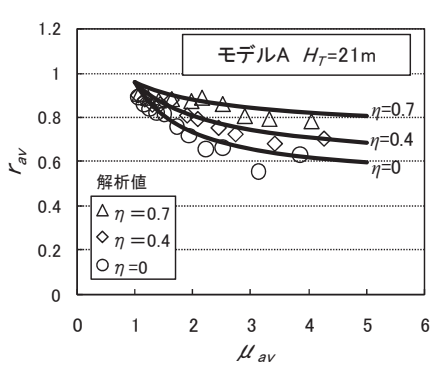

(a) モデル A

図 15 解析結果の $r_{a v}$

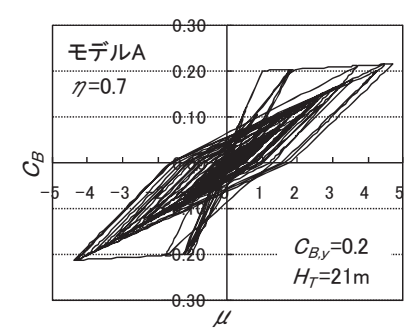

(a) モデル $\mathrm{A}(\eta=0.7)$

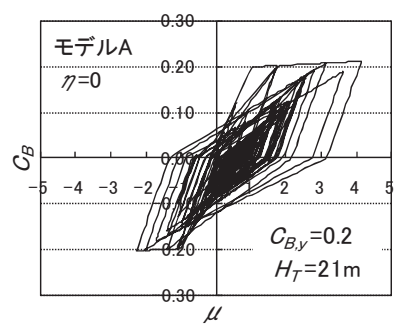

(c) モデル A $(\eta=0)$

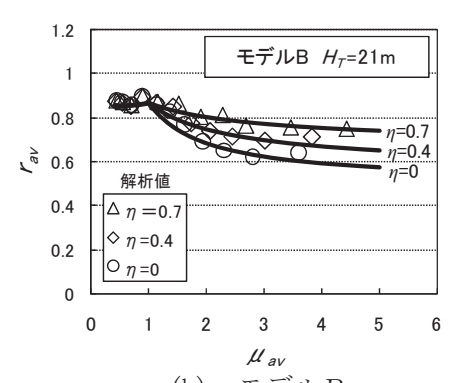

(b) モデル B

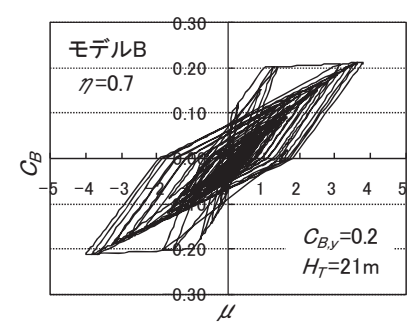

(b) モデル B $(\eta=0.7)$

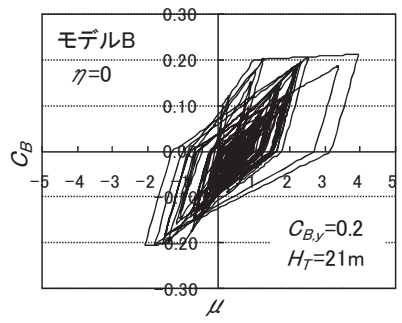

(d) モデル B $(\eta=0)$
図 $16 C_{B}-\mu$ の関係一例

た $C_{B}-\mu$ 関係の一例 (図 8 と同一の模擬地震動による結果) を示す。 $\eta=0$ の場合は応答に偏りが生じているが、 $\eta=0.7$ の場合は偏りが 小さい。

\section{4. 非対称定常応答状態を想定した等価線形化法}

\section{1 応答値の算定法}

図 17 に、偏りが生じた場合の非対称の定常応答状態を示す。こ の場合、等価剛性 $\left(K_{e}^{*}\right)$ および履歴面積 $\left(\Delta W^{*}\right)$ は、対称定常応答 状態のもの $\left(K_{e}\right.$ および $\left.\Delta W\right)$ とは異なったものになる。ここでは、 これらの影響を考慮した応答值の算定法を検討する。

図 18 (a) は対称定常応答状態の場合における応答スペクトルと応 答值 $\left(C_{B}\right.$ および $\left.\delta\right)$ の関係を示している。対称定常応答状態におけ る等価周期を $T_{e}$ 、その時の加速度応答スペクトルを $S_{a}$ 、速度応答ス ペクトルを $S_{v}$ 、変位応答スペクトルを $S_{d}$ とする。また、応答時の単 


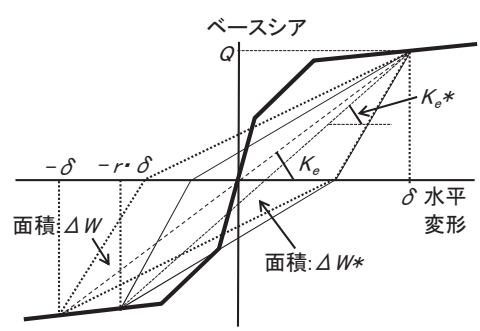

図 17 履歴面積と剛性の変化
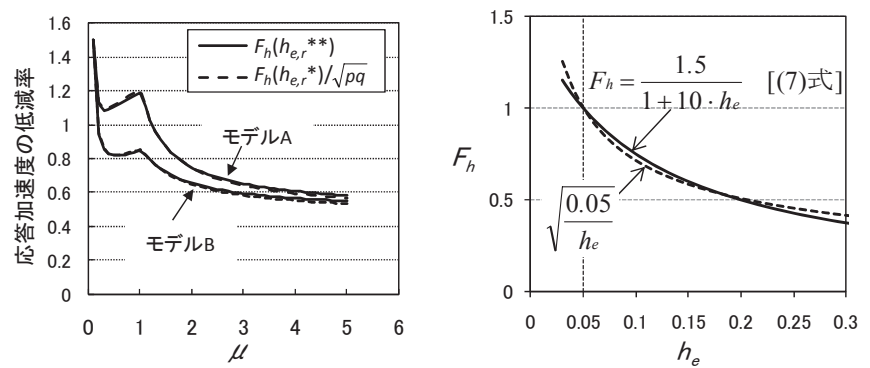

図 $19 F_{h}\left(h_{e, r}{ }^{* *}\right)$ と $\frac{F_{h}\left(h_{e, r}{ }^{*}\right)}{\sqrt{p q}}$ の比較

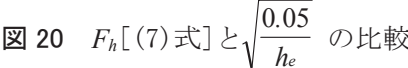

位質量当たりの履歴エネルギーを $\Delta w$ で表すと、 $T_{e}$ に対する $\Delta w$ に よる等価減衰定数 $h_{e, r}$ は (14) 式となる。この $h_{e, r}$ による応答加速度の 低減率を $F_{h}\left(h_{e, r}\right)$ で表すと、(15) 式〜 (17) 式が成り立つ。(17) 式は応 答時の単位質量あたりのポテンシャルエネルギーと $S_{v}$ の関係を表し ている。なお、等価周期 $T_{e}$ は $T_{e}=2 \pi \sqrt{\delta /\left(C_{B} \cdot g\right)}$ である。また、図 2 の Takeda モデルにおいては（14)式は(3)式で表せる。

$$
\begin{aligned}
& h_{e, r}=\frac{1}{4 \pi} \cdot \frac{\Delta w}{1 / 2 \cdot C_{B} \cdot \delta} \\
& C_{B}=\frac{S_{a}}{g} \cdot F_{h}\left(h_{e, r}\right) \quad(15) \quad \delta=S_{d} \cdot F_{h}\left(h_{e, r}\right) \\
& C_{B} \cdot \delta=\frac{S_{a}}{g} \cdot S_{d} \cdot F_{h}\left(h_{e, r}\right)^{2}=\frac{S_{v}{ }^{2}}{g} F_{h}\left(h_{e, r}\right)^{2}
\end{aligned}
$$

一方、図 18 (b) は非対称定常応答状態の場合における応答スペクト ルと応答值の関係を示している。この場合の等価周期を $T_{e}^{*}$ 、その時 の加速度応答スペクトルを $S_{a}{ }^{*}$ 、速度応答スペクトルを $S_{v}{ }^{*}$ 、変位応 答スペクトルを $S_{d}{ }^{*}$ とする。また、ベースシア係数の振幅を $p \cdot C_{B}$ 、 応答変位の振幅を $q \cdot \delta$ で表すと、等価周期 $T_{e}{ }^{*}$ は (18) 式で、等価剛 性 $K_{e}{ }^{*}$ は (19) 式となる。また、最大応答側と反対側の変位は $-r \cdot \delta$ であるので、応答変位の振幅の低減率 $q$ は $(20)$ 式で表される。ベー スシア係数の振幅の低減率を表す $p$ の值は、 $\delta$ と $r$ により対象とす る復元力特性のスケルトンカーブに応じて求めることができる。た だし、降伏後の剛性が 0 の場合は $p$ は 1 に等しい。ここで、非対称 定常応答状態における単位質量当たりの履歴エネルギーを $\Delta w^{*}$ で表 すと、 $T_{e}{ }^{*}$ に対する $\Delta w^{*}$ による等価減衰定数 $h_{e, r}{ }^{*}$ は (21) 式となる。こ の $h_{e, r}{ }^{*}$ による応答加速度の低減率を $F_{h}\left(h_{e, r}{ }^{*}\right)$ で表し、応答スペクトル と応答值の間で $(22)$ 式〜 (24) 式が成り立つものと考える。

$$
\begin{aligned}
& T_{e}^{*}=\sqrt{\frac{q}{p}} \cdot T_{e} \quad \text { (18) } \quad K_{e}^{*}=\frac{p}{q} \cdot K_{e} \quad \text { (19) } \quad q=\frac{1+r}{2} \\
& h_{e, r}{ }^{*}=\frac{1}{4 \pi} \cdot \frac{\Delta w^{*}}{1 / 2 \cdot C_{B} \cdot \delta \cdot p \cdot q}
\end{aligned}
$$

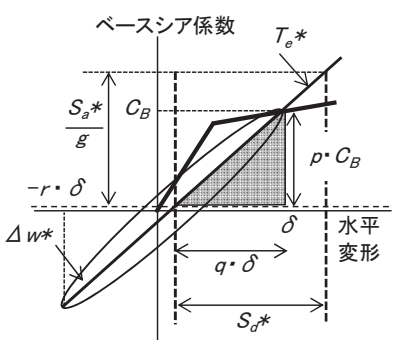

（b）非対称定常応答状態

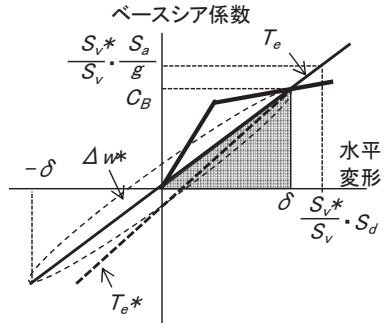

(c) 置換対称定常応答モデル
図 18 応答スペクトルと応答值の関係

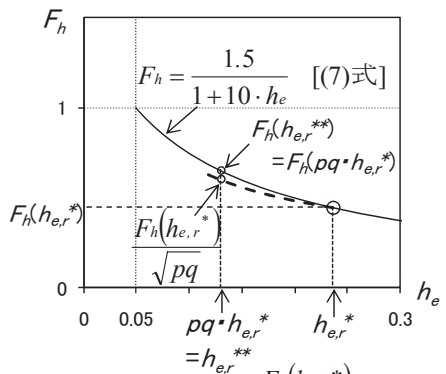

図 $21 F_{h}\left(h_{e, r}{ }^{* *}\right)$ と $\frac{F_{h}\left(h_{e, r}^{*}\right)}{\sqrt{p q}}$ の関係

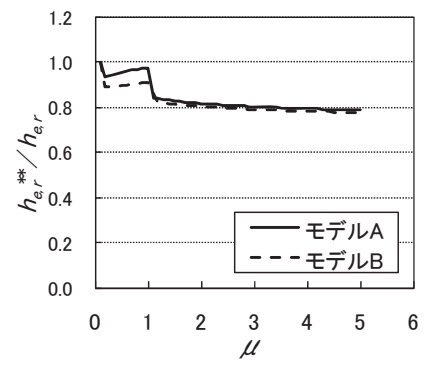

図 $22 h_{e, r}{ }^{* *} / h_{e, r}-\mu$ 関係

$$
\begin{aligned}
& p \cdot C_{B}=\frac{S_{a}^{*}}{g} \cdot F_{h}\left(h_{e, r}{ }^{*}\right) \quad(22) \quad q \cdot \delta=S_{d}{ }^{*} \cdot F_{h}\left(h_{e, r}{ }^{*}\right) \\
& p \cdot q \cdot C_{B} \cdot \delta=\frac{S_{a}^{*}}{g} \cdot S_{d}{ }^{*} \cdot F_{h}\left(h_{e, r}{ }^{*}\right)^{2}=\frac{S_{v}^{* 2}}{g} F_{h}\left(h_{e, r}{ }^{*}\right)^{2}
\end{aligned}
$$

（22）式〜 (24) 式を用いて、非対称定常応答状態の応答值を定める ことも可能であるが、以下では、非対称定常応答状態を対称定常応 答状態に置き換えて応答值を算定することを考える。(22)式の両辺 を $p$ で除すと (25) 式が得られる。また、(23) 式の両辺を $q$ で除すと (26) 式が得られる。ポテンシャルエネルギーは(27)式で表される。

$$
\begin{aligned}
& C_{B}=\frac{S_{v}{ }^{*}}{S_{v}} \cdot \frac{S_{a}}{g} \cdot \frac{F_{h}\left(h_{e, r}{ }^{*}\right)}{\sqrt{p \cdot q}} \quad(25) \quad \delta=\frac{S_{v}{ }^{*}}{S_{v}} \cdot S_{d} \cdot \frac{F_{h}\left(h_{e, r}{ }^{*}\right)}{\sqrt{p \cdot q}} \\
& C_{B} \cdot \delta=\left(\frac{S_{v}{ }^{*}}{S_{v}} \cdot \frac{S_{a}}{g}\right) \cdot\left(\frac{S_{v}{ }^{*}}{S_{v}} \cdot S_{d}\right) \cdot\left(\frac{F_{h}\left(h_{e, r}{ }^{*}\right)}{\sqrt{p \cdot q}}\right)^{2}
\end{aligned}
$$

ここで、（28）式で与えられる $h_{e, r}{ }^{* *}$ による応答加速度の低減率 $F_{h}\left(h_{e, r}{ }^{* *}\right)$ を考える。 $h_{e, r}{ }^{* *}$ は対称定常応答状態を想定した場合の等価 周期 $T_{e}$ に対する $\Delta w^{*}$ によよる等価減衰定数を表しており、 $p q \cdot h_{e, r}{ }^{*}$ に 等しく、かつ、対称定常応答状態における $h_{e, r}[(3)$ 式 $] に \Delta w^{*} / \Delta w$ を 乗じたものに等しい。(25)式〜 (27) 式中の $F_{h}\left(h_{e, r}{ }^{*}\right) / \sqrt{p q}$ を $F_{h}\left(h_{e, r}{ }^{* *}\right)$ に置き換えると (29) 式〜 (31) 式が得られる。なお、置き換えの妥当 性については後述する。

図 18 (c)に(29) 式〜 (31) 式の関係を示す。これらの式は、建築物 の復元力特性が与えられた場合、逐次、変形に応じて等価周期 $T_{e}$ と $T_{e}{ }^{*}$ 求め、 $S_{a}$ と $S_{d}$ の值を $S_{v}{ }^{*} / S_{v}$ を乗じて補正し、さらに、 $h_{e, r}$ を $\Delta$ $w^{*} / \Delta w$ で補正した $h_{e, r}{ }^{* *}$ を用いて $F_{h}$ を算出することにより、通常の 収斂計算で応答值が定まることを示している。

$$
\begin{aligned}
& h_{e, r}{ }^{* *}=\frac{1}{4 \pi} \cdot \frac{\Delta w^{*}}{1 / 2 \cdot C_{B} \cdot \delta}=p q \cdot h_{e, r^{*}}=\frac{\Delta w^{*}}{\Delta w} \cdot h_{e, r} \\
& C_{B}=\frac{S_{v}^{*}}{S_{v}} \cdot \frac{S_{a}}{g} \cdot F_{h}\left(h_{e, r}{ }^{* *}\right) \quad(29) \quad \delta=\frac{S_{v}{ }^{*}}{S_{v}} \cdot S_{d} \cdot F_{h}\left(h_{e, r}{ }^{* *}\right) \\
& C_{B} \cdot \delta=\left(\frac{S_{v}^{*}}{S_{v}} \cdot \frac{S_{a}}{g}\right) \cdot\left(\frac{S_{v}{ }^{*}}{S_{v}} \cdot S_{d}\right) \cdot F_{h}\left(h_{e, r}{ }^{* *}\right)^{2}
\end{aligned}
$$


図 19 に、モデルAとモデルBを用いて前出の $F_{h}\left(h_{e, r}{ }^{*}\right) / \sqrt{p q}$ と $F_{h}\left(h_{e, r}{ }^{*}\right)$ の值を比較した結果を示す。 $r$ の算定には（13)式を、 $F_{h}$ は (7)式を用いた。図 19 に示寸ように両者はほぼ一致しており、この 置き換えは妥当なものと言える。以下に、この理由を説明する。

図 20 は、(7) 式の $F_{h}$ と文献 ${ }^{10)}$ の減衰による応答の低減率 $\sqrt{0.05 / h_{e}}$ （ただし、継続時間は無限大とした）を比較したものである。（7） 式の $F_{h}$ は、 $\sqrt{0.05 / h_{e}}$ と良好に対応しており、ほぼ $1 / \sqrt{h_{e}}$ に比例す る。また、図 21 は、ある $h_{e, r}{ }^{*}$ が与えられた場合における (7) 式によ る $F_{h}\left(h_{e, r}{ }^{* *}\right)$ すなわち $F_{h}\left(p q \cdot h_{e, r}{ }^{*}\right)$ と $F_{h}\left(h_{e, r}{ }^{*}\right) / \sqrt{p q}$ の関係を示してい る。 $p q$ が 1 に近い場合 $\left(r\right.$ が 1 に近い場合) には $F_{h}\left(h_{e, r}{ }^{*}\right) / \sqrt{p q}$ は $F_{h}\left(p q \cdot h_{e, r}{ }^{*}\right)$ の良い近似となる。ただし、この例では、 $p q$ が 1 より かなり小さい場合（ $r$ が 1 よりかなり小さい）場合には両者に差異 が生じる。図 19 の場合には、 $0.81 \leqq p q \leqq 0.95$ であり、 $p q$ が 1 に近 いので、両者はほぼ一致している。

\section{2 解析モデルの等価減衰定数と等価剛性}

対称率 $r$ の算定に(13) 式を用いた場合のモデル A とモデル B の $h_{e, r}{ }^{* *} / h_{e, r}$ と $\mu$ の関係 $\left[(28)\right.$ 式]を図 22 に示す。両モデルとも、 $h_{e, r}{ }^{* *} / h_{e, r}$ の值は、 $\mu \leqq 1$ では $0.9 \sim 1$ 程度の值であるが、 $\mu>1$ ではほぼ 0.8 である。この 0.8 の值は前述の過渡応答の平均的な減衰の効果を 表すための低減係数 0.8 に一致している。

また、同様に、対称率 $r$ の算定に(13) 式を用いた場合の両モデル の $K_{e}{ }^{*} / K_{e}$ と $\mu$ の関係 $\left[(19)\right.$ 式]を図 23 に実線で示す。 $K_{e}{ }^{*} / K_{e}$ の值は 降伏後 $\mu$ の増大に伴い増大寸る。図中の破線は、(19) 式において $p$ $=1$ とした場合のもの[後出の (36) 式]であるが、両者は概衩良好 に対応する。

2 章に示した時刻歴応答解析では、瞬間剛性比例型の粘性減衰を 設定している。文献 $\left.{ }^{11}\right)$ と同様に、定常応答状態における等価剛性 を瞬間剛性とみな寸と、対称定常応答状態 $\left(T_{e} 、 K_{e}\right)$ における瞬間 剛性比例型粘性減衰の減衰定数 $h_{e, n}$ は、図 2 の記号を用いて、ひび 割れ後は (32a) 式で、降伏後は (32b) 式で表される。(32) 式中の $h_{n}$ はひび割れ前の初期周期に対する減衰定数を表している。一方、 非対称定常応答状態 $\left(T_{e}{ }^{*} 、 K_{e}{ }^{*}\right)$ の瞬間剛性比例型粘性減衰の減衰 定数 $h_{e, n}{ }^{*}$ は（33）式となる。ここで、(33) 式の粘性減衰による 1 サ イクルあたりの吸収エネルギーを $\Delta W_{n}{ }^{*}$ とすると、図 18 (c) の置換 対称定常応答モデルにおける等価周期 $T_{e}$ 対する $\Delta W_{n}{ }^{*}$ による等価 減衰定数 $h_{e, n}{ }^{* *}$ は (34) 式で表される。図 24 に、モデル A とモデル B の $h_{e, n}{ }^{* *} / h_{n}$ と $\mu$ の関係 $\left[(34)\right.$ 式]を実線で示す。 $h_{e, n}{ }^{* *} / h_{n}$ の值は $\mu$ の 増大に伴い低下寸る。また、眓中の破線は、(34) 式において $p=1$ としたもの[後出の (37) 式]であるが、両者は良好に対応する。

$h_{e, n}= \begin{cases}\sqrt{\frac{\alpha_{y}}{\mu}\left\{\frac{\mu-\lambda \cdot \alpha_{y}}{1-\lambda \cdot \alpha_{y}}(1-\lambda)+\lambda\right\}} \cdot h_{n} & \left(\lambda \cdot \alpha_{y}<\mu \leqq 1\right) \\ \sqrt{\frac{\alpha_{y}}{\mu}\{1+\beta(\mu-1)\} \cdot h_{n}} & (1<\mu)\end{cases}$

$h_{e, n}{ }^{*}=\sqrt{\frac{K_{e}^{*}}{K_{e}}} \cdot h_{e, n}=\sqrt{\frac{p}{q}} \cdot h_{e, n}$

$h_{e, n}{ }^{* *}=\frac{1}{4 \pi} \cdot \frac{\Delta W_{\mathrm{n}}{ }^{*}}{1 / 2 \cdot K_{e} \cdot \delta^{2}}=p \cdot q \cdot h_{e, n}{ }^{*}=p^{3 / 2} \cdot q^{1 / 2} \cdot h_{e, n}$

以上より、置換対称定常応答モデルにおける $h_{e, r}{ }^{* *} 、 K_{e}{ }^{*} 、 h_{e, n}{ }^{* *}$ は 各々 (28) 式、（19）式、（34）式で表される。ただし、略算的には、 各々 (35) 式、(36)式、(37) 式で近似可能である。

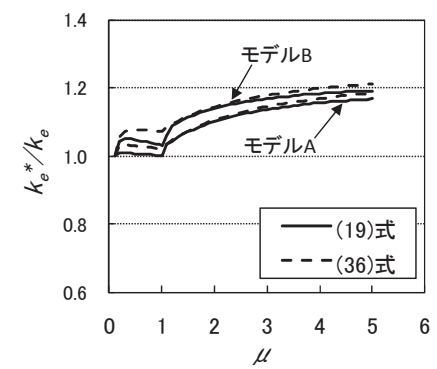

図 $23 K_{e}^{*} / K_{e}-\mu$ 関係

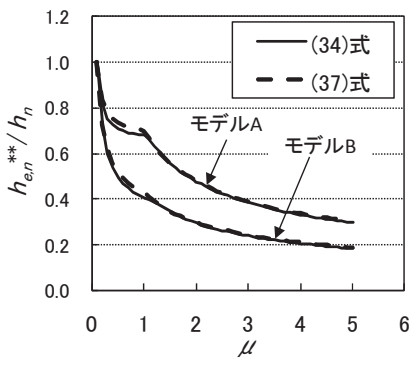

図 $24 h_{e, n} * * / h_{n}-\mu$ 関係

$$
h_{e, r}^{* *}=0.8 \cdot h_{e, r} \quad(35) \quad K_{e}^{*}=\frac{1}{q} \cdot K_{e} \quad \text { (36) } \quad h_{e, n}^{* *}=\sqrt{q} \cdot h_{e, n}
$$

\section{5. 加速度一定領域および速度一定領域からなる設計用応答スペ クトルに対するベースシア係数一最大塑性率関係}

加速度一定領域および速度一定領域の各領域において、非対称 定常応答状態を想定した建築物の $C_{B}-\mu$ 関係を導き、 2 章の時刻歴 応答解析の結果と比較を行う。比較においては、 $F_{h}$ の算定には $(7)$ 式を用い、 $r$ は(13) 式で算定する。また、建築物の等価減衰定数と して、履歴による等価減衰定数に粘性減衰による等価減衰定数を 加えた $(38)$ 式の $h_{e}{ }^{* *}$ を用い、応答加速度の低減率を $F_{h}\left(h_{e}{ }^{* *}\right)$ で表す。 なお、(25) 式〜 (27) 式のように $F_{h}\left(h_{e}{ }^{*}\right) / \sqrt{p q}$ を用いる場合には、建 築物の等価減衰定数として $(39)$ 式の $h_{e}{ }^{*}$ を用いる必要がある。

$$
h_{e}^{* *}=h_{e, r}{ }^{* *}+h_{e, n}{ }^{* *} \quad(38) \quad h_{e}^{*}=h_{e, r}{ }^{*}+h_{e, n}{ }^{*}
$$

(4b) 式で表される加速度一定領域では、 $S_{a}=A 、 S_{v}{ }^{*} / S_{v}=T_{e}{ }^{*} / T_{e}=$ $\sqrt{K_{e} / K_{e}^{*}}$ を前章の (29) 式に代入し、(40a) 式が得られる。また、(4c) 式で表される速度一定領域では、 $S_{a}=A \cdot T_{c} / T_{e} 、 S_{v}{ }^{*} / S_{v}=1$ を(29) 式に代入し、(40b)式が得られる。ただし、(29) 式中の $F_{h}\left(h_{e, r}{ }^{*}\right)$ を $F_{h}\left(h_{e}{ }^{* *}\right)$ とする必要がある。また、(40)式中の $T_{e}$ は (6) 式で与えら れるが、(6)式中の $F_{h}$ は $F_{h}\left(h_{e}{ }^{* *}\right)$ とする必要がある。

$$
C_{B}= \begin{cases}\frac{A}{g} \cdot F_{h}\left(h_{e}^{* *}\right) \cdot \sqrt{\frac{K_{e}}{K_{e}{ }^{*}}} & \left(\text { 加速度一定領域 }: T_{e} \sqrt{\frac{K_{e}}{K_{e}^{*}}}<T_{c}\right) \\ \frac{A}{g} \cdot \frac{T_{c}}{T_{e}} \cdot F_{h}\left(h_{e}^{* *}\right) & \text { (速度一定領域 } \left.: T_{e} \sqrt{\frac{K_{e}}{K_{e}^{*}}} \geqq T_{c}\right)\end{cases}
$$

加速度一定領域の (40a) 式は、(5a) 式に $\sqrt{K_{e} / K_{e}^{*}}$ が乗じられた形 式で表されており、偏りによる等価周期（等価剛性）の変化が応 答值に影響する。一方、速度一定領域の (40b) 式は (5b) 式と同一の 形式であり、速度一定領域では、偏りによる等価減衰定数の変化 により応答值は影響を受けるものの、等価周期（等価剛性）の変 化は応答值に影響を及ぼさないことを示している。

図 25 に、図 6 同様、模擬地震動 25 波に対寸る各解析モデルの 最大塑性率 25 個の平均值 $\mu_{a v}$ と応答ベースシア係数 $C_{B}$ の関係を示 す。図中の 3 本の実線は (40) 式の関係を示している。参考のため、 $\sqrt{K_{e} / K_{e}^{*}}$ を 1 とした(40)式による值を破線で示す。実線は、モデ ル A もモデル B も、速度一定領域では、時刻歴応答解析の $\mu_{a v}$ と良 好に対応している。一方、加速度一定領域では、 $\sqrt{K_{e} / K_{e}^{*}}$ を考慮 することにより、解析值との対応が改善されているが、それでも (40a) 式は解析の平均值より若干大きい值を与えている。

図 26 に、模擬地震動 25 波の変位応答スペクトル $(h=0.05 、 0.1$ 、 $0.15 、 0.2)$ より求めた弾性系の（単位質量当たりの）ポテンシャ 


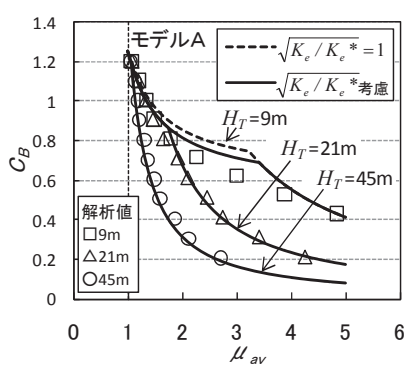

(a) モデルA

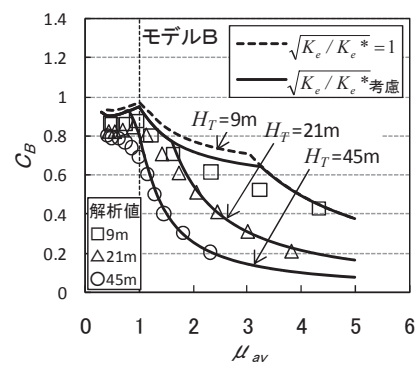

(b) モデル B
図 25 時刻歴応答解析結果と (40) 式の比較

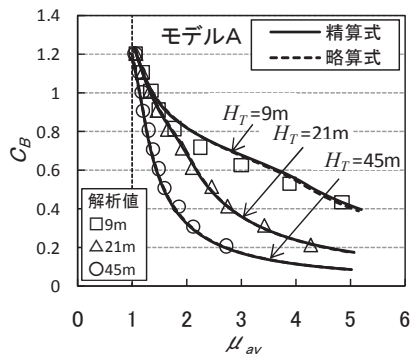

(a) モデル A

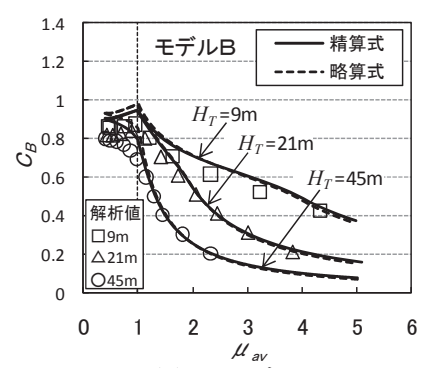

(b) モデル B
図 27 時刻歴応答解析結果と算定值 [(41) 式の $S_{a}$ を使用]の比較

ルエネルギーの平均值（図中の太実線）と(4)式の $S_{a}$ と (7) 式の $F_{h}$ より求めたポテンシャルエネルギー $\left[1 / 2 \cdot S_{a}{ }^{2} \cdot(T / 2 \pi)^{2} \cdot F_{h}{ }^{2}\right]$ の算 定值 (図中の細実線) を比較して示す。 $h=0.1$ および 0.15 の場合 には、明らかに、コーナー周期 $T_{c}$ の近傍での 25 波の平均值は算定 值より小さく、これが前述の図 25 での (40a) 式と解析の平均值と の差異を生じさせる原因になっていると推定される。そこで、保 有水平耐力計算の振動特性係数 $R_{t}{ }^{12)}$ を参考に、 $T_{c}$ 近傍の值を低減 した(41) 式の $S_{a}$ によるポテンシャルエネルギーの算定值を図中に 破線で示す。なお、(41) 式中の $T_{a}$ は $T_{c} / 1.6(=0.54 \mathrm{~s})$ である。 $h=0.05$ の場合を除き、この場合の方が模擬地震動による弾性系のポテン シャルエネルギーとの対応が良くなる。ただし、 $h=0.1$ の場合は、 まだ算定值の方が大きい。

$$
S_{a}= \begin{cases}A & \left(0.16 \leqq T<T_{a}\right) \\ \frac{A \cdot T_{c}}{T} & \left(T_{a} \leqq T<2 T_{a}\right) \\ & \left(2 T_{a} \leqq T\right)\end{cases}
$$

図 27 は、(41)式の $S_{a}$ を用いた場合の $C_{B}-\mu$ 関係の算定值（図中 の実線）と解析值との対応を示したものである。算定值は図 18 (c) に示した収斂計算により求めた。コーナー周期近傍では若干算定 值の方が大きくなっているものの、算定值は時刻歴応答解析の応 答值のほぼ平均的な值を表しているものと言える。なお、罒中の 破線は、置換対称定常応答モデルおける $h_{e, r}{ }^{* *} 、 K_{e}{ }^{*} 、 h_{e, n}{ }^{* *}$ の算定に おいて、前述の略算式 [(35) 式、（36) 式、（37) 式]を用いた場合で ある。実線で示した精算式 [(28)式、（19）式、（34）式]を用いた場 合より、モデル B の $\mu<1$ の領域において幾分応答が大きくなるが、 それ以外は大きな差異はなく、略算式を用いても良好に対応する。

なお、 $S_{a}$ として (41) 式を用いる上記の算定值の計算には煩雑な 収斂計算を要する。そこで、 $S_{a}$ として (4) 式を用い、かつ、コーナ 一周期近傍のエネルギー入力の低下を近似的に考慮する方法とし て、(40a) 式にさらに補正係数 $\alpha$ を乗じた $C_{B}-\mu$ 関係を(42) 式に

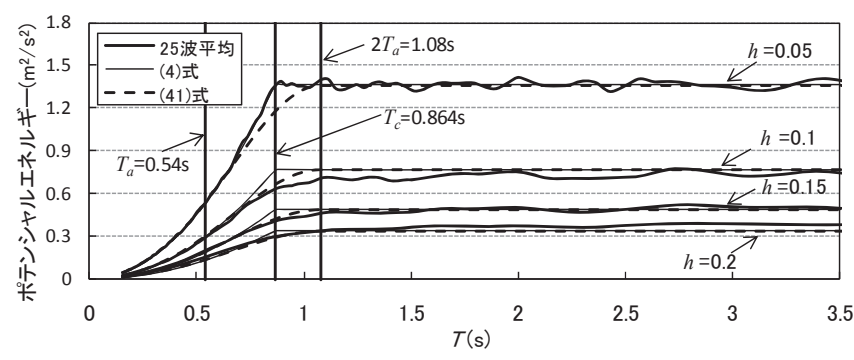

図 26 模擬地震動による弾性系のポテンシャルエネルギー

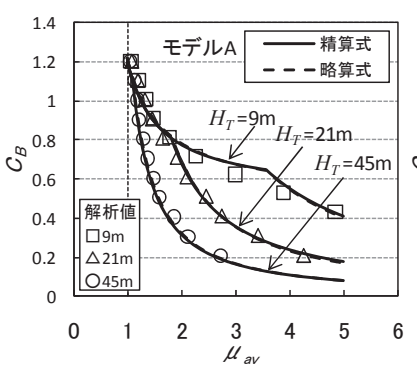

(a) モデル A

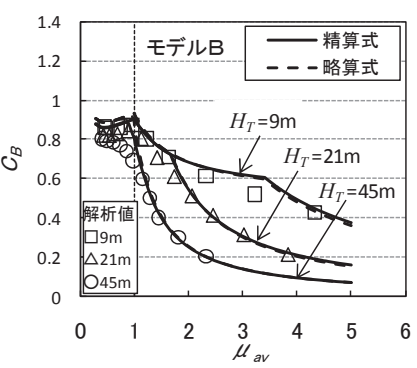

(b) モデル B
図 28 時刻歴応答解析結果と (42) 式 $[\alpha=0.95]$ の比較

示す。また、図 28 に $\alpha=0.95$ とした (42) 式と解析結果との対応を 示す。図中実線が精算式 [(28) 式、（19) 式、（34）式]を用いた場合 で、破線が略算式 $[(35)$ 式、（36) 式、（37) 式]を用いた場合である。 加速度一定領域の $(42 \mathrm{a})$ 式に一定值の $\alpha$ を導入したことは、この領 域の加速度応答スペクトルの值を $\alpha$ 倍したことに相当する（コー ナ一周期は $T_{c} / \alpha$ となる)。したがって、図 25 の場合に比べ、コー ナ一周期近傍では解析值との対応は良くなっているが、モデル $\mathrm{A}$ の $\mu=1$ 近傍においては解析值より若干小さな值を示している。し かしながら、全体的に見れば、 $\alpha=0.95$ とした (42) 式は時刻歴応 答解析の応答值のほぼ平均的な值を表していると言える。

$$
C_{B}= \begin{cases}\alpha \cdot \frac{A}{g} \cdot F_{h}\left(h_{e}^{* *}\right) \cdot \sqrt{\frac{K_{e}}{K_{e}{ }^{*}}} & \left(\text { 加速度一定領域 : } T_{e} \sqrt{\frac{K_{e}}{K_{e}{ }^{*}}}<\frac{T_{c}}{\alpha}\right) \\ \frac{A}{g} \cdot \frac{T_{c}}{T_{e}} \cdot F_{h}\left(h_{e}^{* *}\right) & \left(\text { 速度一定領域 : } T_{e} \sqrt{\left.\frac{K_{e}}{K_{e}{ }^{*}} \geqq \frac{T_{c}}{\alpha}\right)}\right.\end{cases}
$$

\section{6. まとめ}

本論に示した主要な知見を以下に示す。

(1)曲げ降伏が先行する鉄筋コンクリート造建築物の復元力特性と して Takeda モデル $(\eta=0.4)$ 、入力地震動としてランダム位相の 模擬地震動 25 波を用いた 1 自由度系の時刻歴応答解析の結果よ り、告示による応答の評価法は、ひび割れ領域の履歴減衰が小 さい場合は比較的良好に応答結果と対応するが、ひび割れ領域 の履歴減衰が大きい場合には忘答結果と整合しないことを示し た。

(2)時刻歴応答解析 [Takeda モデル $(\eta=0.4)]$ の結果には応答の偏り (正側と負側の各々の最大応答変位の差異) が存在する。解析 值の偏りの分析から、偏りと最大応答変位との間に明瞭な相関 関係があることを示した。

(3)応答の 1 サイクルにおいて、正側と負側の吸収エネルギーの対 称性を仮定し、上記(2)の応答の偏りを評価する対称率の算定式 [(13) 式]を導いた。算定式はランダム位相の模擬地震動 25 波の 
時刻歴応答解析における対称率の平均值と良好に対応する。

(4)上記(3)の応答の偏りの評価式に基づき非対称定常応答状態を想 定し、偏りが生じた場合の Takeda モデルの等価減衰定数および 等価剛性の検討を行い、偏りを考慮した最大応答変位の算定法 を示した。また、偏りを考慮した Takeda モデル $(\eta=0.4)$ の等 価減衰定数および等価剛性の略算式 [(35) 式および(36) 式]を示 し、その有効性を示した。ただし、(35) 式中の低減係数 0.8 は、 復元力特性モデルの履歴性状に依存する。履歴性状が異なる場 合の低減係数や応答結果との整合性については今後検討する必 要がある。

(5)加速度一定領域および速度一定領域からなる設計用応答スペク トルに対し、上記(4)の算定法に基づき、建築物のベースシア係 数一最大塑性率関係を与える算定式 [(40)式および(42)式]を示 した。(42) 式 $[\alpha=0.95]$ は、ランダム位相の模擬地震動 25 波の 時刻歴応答解析 $[$ Takeda モデル $(\eta=0.4)]$ における最大塑性率の 平均值と良好に対応寸る。

なお、偏りを考慮した応答值の算定法に関し、本論では、ランダ ム位相を用いた模擬地震動による解析結果との対応を示した。設 計に多用される既往の観測波の位相特性を用いた模擬地震動によ る解析結果との対応については別の機会に報告する。

\section{参考文献}

1)平成 12 年建設省告示第 1457 号（最終改正 平成 19 年 5 月 18 日 国土交 通省告示第 598 号)

2) 柴田明徳 : 最新 而震構造解析 第 2 版、森北出版(侏)、2003

3) 中村友紀子、壁谷澤寿海 : 瞬間エネルギーを用いた等価線形化法による弾 塑性応答変形の推定、第 10 回日本地震工学シンポジウム、pp. 2573-2578、 1998. 11

4) 中村友紀子、壁谷澤寿海：地震動特性に基づく応答変位の時刻歷期待值の 評価法、日本建築学会構造系論文集、第 532 号、pp. 51-56、2000.6

5) 岡野創、宮本裕司 : 等価線形化法に基づく応答評価式、エネルギーバラン スに基づく考察と限界変形の超過確率の評価への適用、日本建築学会構造 系論文集、第 562 号、pp. 45-52、2002. 12

6) Takeda, T., Sozen, M.A., Nielsen, N.N. : Reinforced concrete response to simulated earthquakes, Journal of the Structural Division, ASCE, Vol.96, pp. $2557-2573,1970.12$

7)平石久廣、稲井栄一、和田寿一、福島徹 : 鉄筋コンクリート造建築物の地 震応答と耐震性能評価に関寸る研究、日本建築学会構造系論文集、第 613 号、pp. 105-112、2007.3

8) 稲井栄一、北村梢、丸橋奈々子、平石久廣 : 鉄筋コンクリート造建築物の 必要水平耐力に関寸る研究、日本建築学会構造系論文集、第 73 巻、第 633 号、pp. 1993-2000、2008. 11

9) 建設省建築研究所、日本建築センター：設計用入力地震動作成手法技術指 針（案）、1992

10) 大鳥靖樹、小山慶樹、坂場律和 : 非定常入力に対寸る RMS 応答の減衰補正 係数に関する検討、日本建築学会大会学術講演梗概集. B-1、pp249-250、 2004.8

11) 吉川和秀、岡野創、小鹿紀英 : 高次モードを考慮した等価線形化法による 単層偏心建物の地震応答評価、日本建築学会構造系論文集、第 621 号、 pp. 57-65、2007. 11

12) 国土交通省住宅局建築指導課ほか監修: 2007 年版 建築物の構造関係技術 基準解説書、2007. 8

13) Eiichi Inai, Hisahiro Hiraishi, Kozue Kitamura: Required Base Shear for Reinforced Concrete Buildings Based on Equivalent Linearization Method,
Proceedings of the 14th WCEE, Paper ID No.08-02-0028 (CD-Rom), Oct., 2008

\section{付録 $1 ：$ 応答の 1 サイクルにおける正側負側の $1 / 2$ サイクルの吸収エネルギ 一の検討}

最初に、対称率 $r$ の変動係数が最も大きいモデル B $H_{T}=9 \mathrm{~m} 、 C_{B, y}=0.4$ の 場合 [本文図 10 および図 6 (b) 参照] を例に、正側負側の $1 / 2$ サイクルの吸 収エネルギーの大きさを検討した結果を示す。付図 1 (a)に解析により求めた $C_{B}-\mu$ 関係の一例 $[$ ケース 1] を示寸 (正負の最大応答変位のうち絶対值の大き な応答変位を生じる側を図の正側とする。以下同様)。

まず、最大応答変位に達する過程を明確にするために、付図 1 (a)において、 降伏が生じるまでは弾性として扱い、降伏後、正負ともにスケルトンカーブ 上での経験最大変位を超えた応答部分のみを取り出した（正負で各々最大応 答変位が生じた後荷重 0 になるまでとする)。その結果を付図 1 (b) に示す。

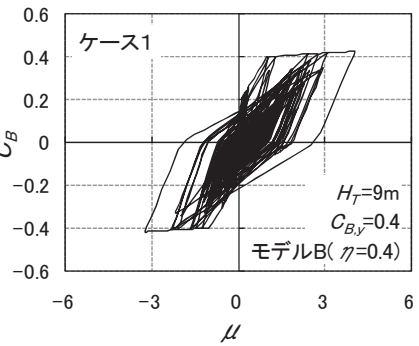

(a) 解析結果

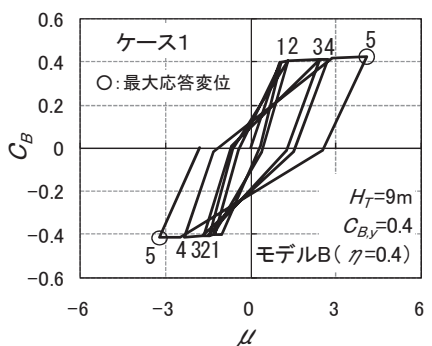

（b）最大応答変位に至る過程
付図 $1 C_{B}-\mu$ 関係（ケース 1 )

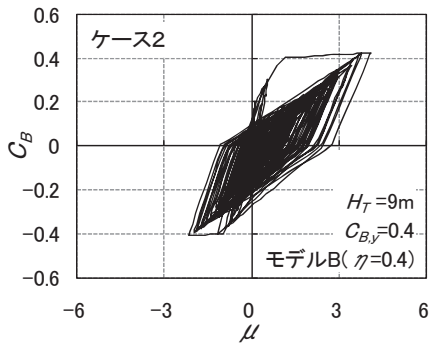

(a) 解析結果

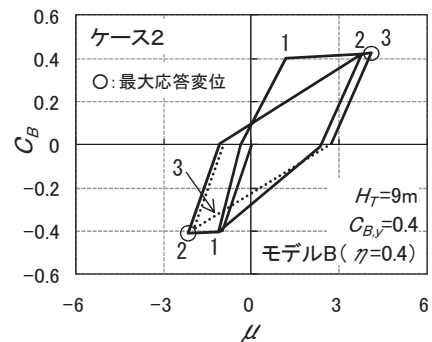

（b）最大応答変位に至る過程

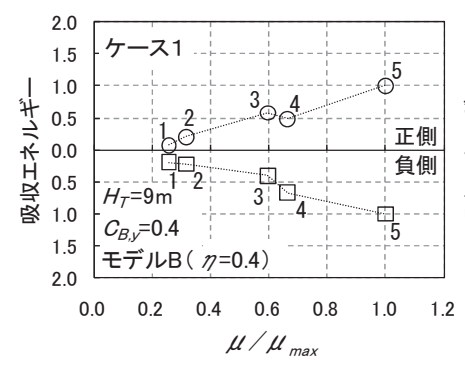

(a) ケース 1

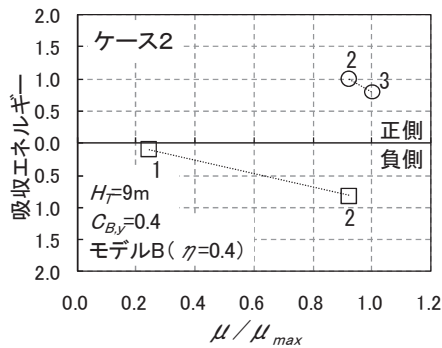

(b) ケース 2
付図 3 正側および負側の $1 / 2$ サイクルの吸収エネルギーの比較

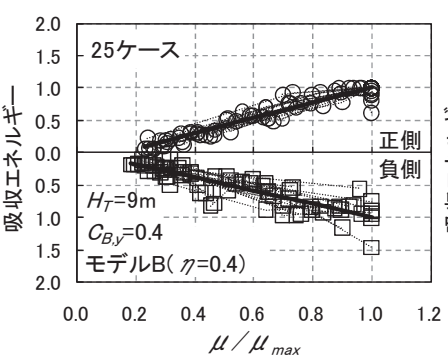

(a) モデル B $, H_{T}=9 \mathrm{~m}, C_{B, y}=0.4$

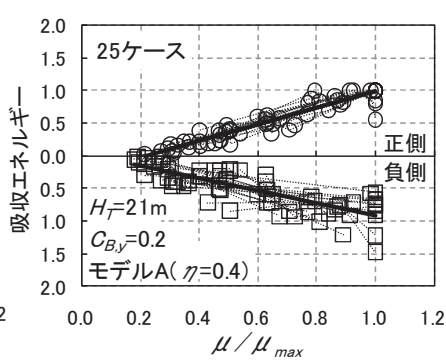

(b) モデル A, $H_{T}=21 \mathrm{~m}, C_{B, y}=0.2$
付図 4 正側および負側の $1 / 2$ サイクルの吸収エネルギーの比較 
この場合、5 回目の繰り返しサイクルにおいて正負とも最大応答変位が生じ ている。なお、繰り返しサイクルは正側を起点とし、正負いずれかで降伏が 生じた場合を 1 サイクル目とした。図中の数字は繰り返しサイクルの回数を 表している。各繰り返しサイクルにおける正側および負側の $1 / 2$ サイクルの 吸収エネルギーは図の面積から算出できる。ケース 1 の算出結果を付図 3 (a) に示す。付図 3 の縦軸は、各繰り返しサイクルにおける正側および負側の吸 収エネルギーを、正側の最も大きな吸収エネルギーで基準化した值で示して おり、正側の吸収エネルギーは軸の上側に○印で、負側の吸収エネルギーは 軸の下側に口印で示している。また、付図 3 の横軸は、各繰り返しサイクル における正側ピークの塑性率 $\mu$ を最大塑性率 $\mu_{\text {max }}$ （正側）で基準化した $\mu / \mu_{\text {max }}$ を表している。付図 3 (a)の場合、全体的にみれば $\mu / \mu_{\max }$ の増大とともに吸収 エネルギー量は増大しており、また、正側と負側の吸収エネルギー量は各繰 り返しサイクルでほぼ等しくなっている。

付図 2 (a) はケース 1 と入力地震動が異なる別の $C_{B}-\mu$ 関係 [ケース 2] を示 している。また、付図 $2(\mathrm{~b})$ はケース 1 と同様に取り出した最大応答変位に至 る過程を示している。ケース 2 はケース 1 と異なり、2 サイクル目の正側で ほぼ最大応答変位に近い応答が生じた後、その負側で負の最大応答変位が生 じている。その後、応答が正側に若干シフトし、3 サイクル目正側で最大応 答変位が生じ、その負側では 2 サイクル目負側で生じた変位より小さな変位 しか生じていない。このような応答のシフトにより最大応答変位が生じる場 合は、徐々に応答が増大したケース 1 の応答過程と異なるものであるが、シ フト量が大きくなければ、シフトが生じる前の繰り返しサイクルで、ほぼ正 負の最大応答変位が生じていると捉えることができる。付図 3 (b) にケース 1 の場合と同様に作成したケース 2 における正側負側の吸収エネルギーの比較 を示す。なお、この例のように最初に負側で降伏が生じる場合は 1 サイクル 目の繰り返しサイクルの正側のピークの塑性率は 1 とみなしている。

付図 4(a) は上記のケース 1 およびケース 2 ならびに他の地震動による応答 の結果も併せて、合計 25 ケースについて 1 つの図に表示したものである。艮 中の実線は正側負側の各々のデータを線形近似したものであり、ばらつきが あるものの、平均的には各繰返しサイクルにおける正側負側の吸収エネルギ 一はほぼ等しいものと捉えることができる。

付図 4 (b) は、付図 4 (a) に示したモデル B の $H_{T}=9 \mathrm{~m} 、 C_{B, y}=0.4$ の場合と同様、 対称率 $r$ のばらつきが大きいモデル $\mathrm{A} の ~ H_{T}=21 \mathrm{~m} 、 C_{B, y}=0.2$ について、25 波 の応答結果の正側負側の $1 / 2$ サイクルの吸収エネルギーを比較したものであ る。この場合も付図 4 (a)の場合とほぼ同様な結果が得られている。

\section{付録 $2:$ 本文 $(9)$ 式の誘導}

本文図 13 の応答過程に基づき本文(9)式を誘導する。まず、図 13 (a)の状 態を考える。図 13 (a) は 1 回目の繰り返しサイクルを想定しており、正側の $1 / 2$ サイクルの吸収エネルギーを $A_{1}$ 、負側の $1 / 2$ サイクルの吸収エネルギー
を $B_{1}$ とする。 $A_{1}$ および $B_{1}$ は、本文図 12 および図 13 (a) 中の記号を用いて、(付 -1)式および(付一-2)式で表すことができる。 $A_{1}=B_{1}$ の仮定より、（付－3）式 [本文(9)式、ただし $i=1$ の場合]が得られる。

$$
\begin{aligned}
& A_{1}=\mu_{p, 1}-\frac{1}{2 \xi} \mu_{p, 1}{ }^{\eta}-\frac{1}{2} \\
& B_{1}=\mu_{m, 1}-\frac{1}{2 \xi} \mu_{m, 1}{ }^{\eta}+\frac{1}{2} \mu_{p, 1}-\frac{1}{2 \xi} \mu_{p, 1}{ }^{\eta}-\frac{1}{2} \\
& \mu_{m, 1}-\frac{1}{2 \xi} \mu_{m, 1}{ }^{\eta}=\frac{1}{2} \mu_{p, 1}
\end{aligned}
$$

次に図 13 (b) の状態を考える。図 13 (b) は 2 回目の繰り返しサイクルを想定 しており、正側の $1 / 2$ サイクルの吸収エネルギーを $A_{2}$ 、負側の $1 / 2$ サイクル の吸収エネルギーを $B_{2}$ とする。 $A_{2}$ および $B_{2}$ は、図 12 および図 $13(\mathrm{~b})$ 中の記 号を用いて、(付一-4) 式および(付一-5)式で表すことができる。 $A_{2}=B_{2}$ の仮定 より(付一6)式が得られる。ここで、図 13 (b) の状態は 1 回目の繰り返しサイ クルで $A_{1}=B_{1}$ が成り立っていることを前提としているので、(付一-6)式中の 右辺の第 2 項、第 3 項および第 4 項の和は (付 - 3) 式より 0 となり、（付－7） 式[本文 (9)式、ただし $i=2$ の場合]が得られる。

$$
\begin{aligned}
& A_{2}=\mu_{p, 2}-\frac{1}{2 \xi} \mu_{p, 2}{ }^{\eta}-\frac{1}{2} \mu_{p, 1}+\frac{1}{2} \mu_{m, 1}-\frac{1}{2 \xi} \mu_{m, 1}{ }^{\eta} \\
& B_{2}=\mu_{m, 2}-\frac{1}{2 \xi} \mu_{m, 2}{ }^{\eta}+\frac{1}{2} \mu_{p, 2}-\frac{1}{2 \xi} \mu_{p, 2}{ }^{\eta}-\frac{1}{2} \mu_{m, 1} \\
& \mu_{m, 2}-\frac{1}{2 \xi} \mu_{m, 2}{ }^{\eta}=\frac{1}{2} \mu_{p, 2}-\frac{1}{2} \mu_{p, 1}+\mu_{m, 1}-\frac{1}{2 \xi} \mu_{m, 1}{ }^{\eta} \\
& \mu_{m, 2}-\frac{1}{2 \xi} \mu_{m, 2}{ }^{\eta}=\frac{1}{2} \mu_{p, 2}
\end{aligned}
$$

同様に、3 回目以降の繰り返しサイクルにおいても、その繰り返しサイク ルおよび前段階のすべての繰り返しサイクルで、正側と負側の $1 / 2$ サイクル の吸収エネルギーが等しいと仮定することにより本文 (9) 式が得られる。

なお、上記の誘導では、前段階のすべての繰り返しサイクルで正側と負側 の $1 / 2$ サイクルの吸収エネルギーが等しいと仮定しているが、付図 4 に示し たように小振幅時の吸収エネルギーは、最大応答が生じるような大振幅時の 吸収エネルギーに比べ小さく、応答の初期段階の小振幅時の正負の吸収エネ ルギーのばらつきが最大応答に大きく影響することはないと考えられる。

(2009年 6 月 30 日原稿受理，2010年 1 月 8 日採用決定） 